Rev. Biol. Trop., 47(4): 1117-1119, 1999

www.ucr.ac.cr www.ots.ac.cr www.ots.duke.edu

COMMUNICATION

\title{
Dry season activity, movement, habitat and den utilization of nine-banded armadillo (Dasypus novemcinctus) in neotropical dry forest, Costa Rica
}

\author{
Christopher Vaughan and Sheila Shoenfelder \\ Wildlife Management Program for Mesoamerica, Universidad Nacional, Costa Rica and Associated Colleges of the \\ Midwest, Apartado 10265, San Jose, Costa Rica. Fax 506-237-7036, email: cvaughan@ facstaff.wisc.edu
}

Received 26-XI-1998. Corrected 10-VI-1999. Accepted 16-VI-1999.

\begin{abstract}
Resumen: Se estudió el armadillo (Dasypus novemcinctus Linnaeus) en Palo Verde, Costa Rica ( $10^{\circ} 30^{\prime} \mathrm{N}$ y $85^{\circ} 30^{`} \mathrm{~W}$ ) equipando siete animales con radiotransmisores. No hubo actividad en 0600-1500 h y ésta fue máxima en 1800-2100 h (95\%). Los desplazamientos nocturnos fueron de $421.4 \mathrm{~m}$ (223-835 m. Seis individuos usaron 14 madrigueras en cuatro tipos de hábitat.
\end{abstract}

The nine-banded armadillo (Dasypus novemcinctus Linnaeus) has the greatest range and is the most studied of the 20 Dasypodidae species (Galbreath 1982, McBee \& Baker 1982). It is an important food source for humans and wildlife in Central America, but no ecological information exists there for management purposes (Carrillo \& Vaughan 1994). For these reasons, research on activity, movements, habitat and den use of nine-banded armadillos was carried out in Palo Verde National Park (PV), a tropical dry forest life zone located in northwestern Costa Rica $\left(10^{\circ} 30^{\prime} \mathrm{N}\right.$ and $85^{\circ} 30 \mathrm{~W}$ )(Vaughan et al. 1982). For detailed information on PV, see Vaughan et al. (1982). Seven nine-banded armadillos were captured by lifting them up by their tails as they foraged. Each armadillo was measured, weighed and individually marked with a painted number. A "radio telemetry package" was attached with Super Glue epoxy to the lower rear portion of the previously sand papered shell. This radio was constructed by the senior author. It consisted of a SM1 transmitter (AVM Telemetry Company, Dublin, California), two 1.74 volt alkaline batteries (estimated 4-month life expectancy), all covered with a beeswax-paraffin mixture and encased in dental acrylic. An external antenna $15 \mathrm{~cm}$ long was soldered to the radio package at the antenna contact. Armadillos were freed at capture sites within two hours of capture. Radio-telemetry data was taken hourly for $24 \mathrm{~h}$ periods; data collection, vegetation mapping and data analysis followed McCoy et al. (1990) for Tayassu tajacu. Diurnal radio signals from inactive study armadillos led us to den locations. Home ranges were not calculated because of the limited data set.

Three adult males, 3 adult females and one juvenile female nine-banded armadillos were studied from February 25 to March 30, 1982. A total of 432 telemetry "fixes" (18 days of 24-hour time periods) were analyzed for activity, while 227 data points (16 days) between 1600-0600 $\mathrm{h}$ were analyzed for movement and habitat use (Table 1). Activity Patterns: Based on 432 data points, there was no activity between $0600-1500 \mathrm{~h}$, activity was low between 1500-1800 h (sunset)(24\%), maximized between $1800-2100 \mathrm{~h}(95 \%), 2100-2400 \mathrm{~h}(78 \%)$ 
TABLE 1

Characteristics of nine-banded armadillo (Dasypus novemcinctus) weight, movement, habitat use and den use in Palo Verde National Park, Costa Rica. February-March 1982

$\begin{array}{lllllll}\text { Sex } & \begin{array}{l}\text { Wgt } \\ \text { (kg.) }\end{array} & \begin{array}{l}\text { Points } \\ \text { (\# days) }\end{array} & \text { Movement (m/night) } & \begin{array}{l}\text { Habitat use } \\ \text { EF/P/OP/GT/E }\end{array} & \text { den use } \\ 101 & \text { F } & 4.75 & 73(5) & 590,330,328,487,785 & 73 / 0 / 0 / 0 / 0 & 4-E F \\ 102 & \text { F } & 2.85 & 14(1) & 835 & 0 / 14 / 0 / 0 / 0 & 1-\mathrm{P} \\ 103 & \mathrm{M} & 2.95 & 13(1) & 223 & 0 / 0 / 13 / 0 / 0 & 2-\mathrm{OP} \\ 104 & \mathrm{M} & 3.30 & 55(4) & 233,225,440,133 & 0 / 0 / 0 / 55 / 0 & 1-\mathrm{YT} \\ 105 & \mathrm{~F} & 3.75 & 17(1) & 308 & 0 / 17 / 0 / 00 / & \\ 106 & \mathrm{M} & 4.24 & 29(2) & 388,200 & 10 /-\mathrm{P} & \text { 3-P,1-EF } \\ 108 & \mathrm{~F} & 3.37 & 26(2) & 378,328 & & 1-\mathrm{P}, 1-\mathrm{EF} \\ \text { Total } & & & 227(16) & & & \end{array}$

Key: EF-evergreen forest, P-pasture, OP-overgrown pasture, GT-young thicket, E- between EF/P

and $2400-300 \mathrm{~h}(76 \%)$ and fell between 0300$0600 \mathrm{~h}(45 \%)$. Bider (1962) also found D. novemcinctus active between 1700-0400 h, peaking between 2100-2200 h. McDonough and Loughry (1997) found $D$. novemcinctus active throughout $24 \mathrm{~h}$ cycles, maximum at sunset. Armadillos in this study normally entered their burrows about $0600 \mathrm{~h}$, spending daylight hours inactive; only on three occasions were unmarked individuals observed foraging diurnally. The harsh, dry season climate (no rainfall was recorded during the study period) probably influenced low diurnal activity. Clark (1951) observed armadillos in Texas foraging at $1430 \mathrm{~h}$ during extreme dry periods, attributing it to food scarcity, while Kalmbach (1943) calculated that rainy, cool, windy climates induced arthropod activity, triggering armadillo activity. Movement: Nightly movements averaged $421.4 \mathrm{~m}$ and ranged between $223-835 \mathrm{~m}(\mathrm{n}=$ 16, S.D. $=167.1 \mathrm{~m}$ ) with females moving significantly greater distances then males $485.4 \mathrm{~m}$ $(\mathrm{n}=9)$ vs $263.1(\mathrm{n}=7)(\mathrm{p}<0.005)$. These nightly movements were greater then the 387 $\mathrm{m}, 233 \mathrm{~m}$ and $383 \mathrm{~m}$ reported by Clark (1951), Fitch et al. (1952) and Layne and Glover (1977) respectively from studies in North America; however, environmental and methodological differences between studies (time of year, climate, radiotelemetry vs direct observation) make comparisons difficult.. Habitat uti- lization: Four habitat types were mapped in the study area: 1) evergreen forest (EF) categorized by ojoche (Trophis racemosa), yos (Sapium theolcarpum) and tempisque (Mastichodendron capiri); 2) overgrown pasture (OP) characterized by jaragua grass (Hyparrhenia rufa) grass with scattered guacimo trees ( $\mathrm{Gua}$ zuma ulmnifolia), cornizuelo (Acacia cornige$\mathrm{ra}$ ), and poroporo (Cochlospermum vitifolium; 3) mowed pastures (P)(grasses) surrounding the administration area (a swampy pasture formed in a lowland area), and 4) a 4-5 year old thicket of guacimo (GT)(Guazuma ulmnifolia) trees (Table 1). Each of five armadillos used one habitat type (all different) while \#106 and \#108 moved between EF and P, utilizing their edge on $21 \%$ of the observations. Use by Dasypus of more then one habitat type has also been documented by Fitch et al. (1952) and Taber (1945). Den utilization: Six individuals used a total of 14 dens $(n=2.3$ dens each) in four different habitat types (Table 1). Jacobs (1976) calculated an average four dens per armadillo in Mississippi. Armadillo \#105 used a black iguana lizard (Ctenosaura similis) den for an emergency escape. Clark (1951) found $D$. novemcinctus shared dens with cotton mice (Sigmodon hispidus), common opossum (Didelphis marsupialis) and spotted skunk (Mephitis mephitis). In this study, a male and female armadillo shared dens; Kalmbach (1943) 
discovered the same during the breeding season in Texas. Carter and Encarnaga (1983) thought armadillo dens in Brazil fulfilled thermoregulatory and protective functions.

\section{REFERENCES}

Bider, J.M. 1962. Dynamics and the tempero-spatial relaions of a vertebrate community. Ecology 43: 634-646.

Carrillo, E. \& C. Vaughan (eds.). 1994. La vida silvestre de Mesoamerica: Diagnostico y estrategia para su conservacion. Universidad Nacional, Heredia, Costa Rica. 360 p.

Carter, T. S. \& C. D. Encarnaga. 1983. Characteristics and use of burrows by four species of armadillos in Brazil. J. Mammal. 64:103-108.

Clark, W.K. 1951. Ecological life history of the armadillo in the eastern Edward's Plateau region. Amer. Midland Nat. 46: 337-358.

Fitch, H.S., P. Goodrum \& C. Newman. 1952. The armadillo in the southeastern United States. J. Mammal. 33: 21-37.

Galbreath, G. J. 1982. Armadillo. p 71-79. In J. A. Chapman \& G. A. Feldhamer (eds.). Wild mammals of North America. Johns Hopkins University, Baltimore.

Jacobs, F.J. 1976. Behavior and space usage patterns of the nine-banded armadillo (Dasypus novemcinctus) in southwestern Mississippi. M.S. Thesis. Cornell University, Ithaca, New York.

Kalmbach, E.R. 1943. The armadillo: its relation to agriculture and game. Texas Game, Fish and Oyster Commission. Austin, Texas. $60 \mathrm{p}$.

Layne, J. N. \& D. Glover. 1977. Home range of the armadillo in Florida. J. Mammal. 58:411-413

McBee, K. \& R. Baker. 1982. Dasypus novemcintus. Mammalian Species 162:1-9.

McCoy, M. B, C. S. Vaughan, M. A. Rodriguez \& K. Kitchen. 1990. Seasonal movement, activity and diet of the collared peccary (Tayassu tajacu) in Costa Rican dry forest. Vida Silvestre Neotropical 2:6-20.

McDonough, C. M. \& W. J. Loughry. 1997. Influences on activity patterns in a population of nine-banded armadillos. J. Mammal. 78:932-941.

Taber, F. 1945. Contributions on the life history and ecology of the nine-banded armadillo. J. Mamm. 26:211-226

Vaughan, C., G. Canessa, M. McCoy, M. Rodriguez, J. Bravo, J. Sanchéz, R. Morales, T. Hawkins, E. Crozier, D. Shaffer, M. Rodríguez \& F. Hodgson. 1982. Plan de manejo y desarrollo del Refugio Nacional de Fauna Silvestre Rafael Lucus Rodríguez Caballero (Palo Verde). Universidad Nacional, Heredia, Costa Rica. 272 p. 